\title{
Intra-laboratory pre-validation of a human cell based in vitro angiogenesis assay for testing angiogenesis modulators
}

\section{Jertta-Riina Sarkanen ${ }^{1}$, Marika Mannerström ${ }^{1}$, Hanna Vuorenpää ${ }^{1}$, Jukka Uotila ${ }^{2}$, Timo Ylikomi ${ }^{1,3,4}$ and Tuula Heinonen ${ }^{1}$}

\author{
1 Finnish Center for Alternative Methods, Medical School, University of Tampere, Tampere, Finland \\ 2 Department of Obstetrics and Gynecology, Tampere University Hospital, Tampere, Finland \\ ${ }^{3}$ Department of Cell Biology, Medical School, University of Tampere, Tampere, Finland \\ ${ }^{4}$ Department of Clinical Chemistry, Tampere University Hospital, Tampere, Finland
}

\section{Edited by:}

Thomas Hartung, Universität Konstanz, Germany

\section{Reviewed by:}

Mosaad A. Abdel-Wahhab, National

Research Centre, Egypt

Thomas Hartung, Universität Konstanz, Germany

\section{*Correspondence:}

Jertta-Riina Sarkanen, Finnish Center for Alternative Methods, Medical

School, University of Tampere,

Medisiinarinkatu 3, Fl-33014 Tampere,

Finland.

e-mail: riina.sarkanen@uta.fi
The developed standardized human cell based in vitro angiogenesis assay was intra-laboratory pre-validated to verify that the method is reliable and relevant for routine testing of modulators of angiogenesis, e.g., pharmaceuticals and industrial chemicals. This assay is based on the earlier published method but it was improved and shown to be more sensitive and rapid than the previous assay. The performance of the assay was assessed by using six reference chemicals, which are widely used pharmaceuticals that inhibit angiogenesis: acetyl salicylic acid, erlotinib, 2-methoxyestradiol, levamisole, thalidomide, and anti-vascular endothelial growth factor. In the intra-laboratory pre-validation, the sensitivity of the assay (upper and lower limits of detection and linearity of response in tubule formation), batch to batch variation in tubule formation between different Master cell bank batches, and precision as well as the reliability of the assay (reproducibility and repeatability) were tested. The pre-set acceptance criteria for the intra-laboratory pre-validation study were met. The relevance of the assay in man was investigated by comparing the effects of reference chemicals and their concentrations to the published human data. The comparison showed a good concordance, which indicates that this human cell based angiogenesis model predicts well the effects in man and has the potential to be used to supplement and/or replace of animal tests.

Keywords: angiogenesis, intra-laboratory method pre-validation, FGF-2, VEGF, tubule formation, in vitro assay

\section{INTRODUCTION}

Angiogenesis, the formation of new blood vessels, is a multistep process regulated by an interplay of pro- and anti-angiogenic factors. The steps involved are: endothelial cell proliferation, migration, differentiation, and tubule formation, as well as stabilization of newly formed blood vessels by a layer of pericytes and smooth muscle cells (Beilmann et al., 2004; Folkman, 2006; Nillesen et al., 2007). Angiogenesis is involved in critical physiological processes such as in embryonic development, wound healing, and female reproductive cycle (Friis et al., 2003; Berthod et al., 2006; Norrby, 2006), as well as in pathologic processes such as in tumor development and macular degeneration (Friis et al., 2003), rheumatoid arthritis (Friis et al., 2003; Middleton et al., 2004), ischemic diseases (van Weel et al., 2008; Cao, 2009), endometriosis (Rogers et al., 2009), and psoriasis (Folkman, 2006).

Due to complex interactions during angiogenesis, the evaluation of factors that affect angiogenesis would optimally be studied in vivo (Auerbach et al., 2003). The most commonly used in vivo angiogenesis assays include chick chorioallantoic membrane (CAM) assay, Matrigel plug assay, zebrafish embryo system, corneal micropocket assay, rat/mouse hind limb ischemia model, rat aortic ring assay, intradermal angiogenesis assays, and Xenopus tadpole assay (Auerbach et al., 2003). These in vivo assays are used to measure new blood vessel formation by pro- and anti-angiogenic factors and compounds (Akhtar et al., 2002; Auerbach et al., 2003; Norrby, 2006; Ishikane et al., 2008; Ziche and Morbidelli, 2009), and to study tumor angiogenesis (Auerbach et al., 2003; Norrby, 2006) or embryonic, and organogenic angiogenesis (Norrby, 2006). Despite the advantage of providing more information on complex cellular and molecular interactions compared to in vitro models (Norrby, 2006), animal models are burdened by several disadvantages such as variability, animal-specificity, and unethical procedures (Norrby, 2006; Ishikane et al., 2008). The current in vivo assays are not pertinent to human diseases as regards both efficacy and relevance (Norrby, 2006). Therefore, human cell based (in vitro) assays would have potential to be more predictive than animal models when investigating the effects in man.

Current in vitro angiogenesis assays include cell proliferation and cell migration assays, tubule formation assays, and organ culture assays (Auerbach et al., 2003; Ucuzian and Greisler, 2007). Three-dimensional in vitro assays permit cell-to-cell interactions, but responses are often difficult to evaluate and quantitate. Most cell culture assays (e.g., tubule formation assays in collagen or Matrigel, cell motility assays, trans-membrane assays, or cell proliferation assays) only reflect one single step of angiogenesis (Auerbach et al., 2003). An ideal in vitro assay would measure both stimulation and inhibition (Bishop et al., 1999; Norrby, 2006) and provide quantitative measurement of the tubule formation (Norrby, 2006). Although tubule formation in vitro does not cover the whole angiogenesis process, it effectively mimics the key steps, i.e., migration and differentiation of endothelial cells (Donovan et al., 2001). 
The objective of the study was to intra-laboratory pre-validate the optimized test method for testing of angiogenesis modulators in routine use to replace and/or supplement animal experiments. The co-culture assay published by Bishop et al. (1999) and Donovan et al. (2001) was further developed, optimized and finally pre-validated in the laboratory. All critical steps including cell isolation procedure, cell number, cell passage, culture time, and tubule formation procedure as well as microscopic analysis were thoroughly investigated and optimized before the intra-laboratory pre-validation. During the intra-laboratory pre-validation, the performance of the assay was assessed by using six reference chemicals, inhibitors of angiogenesis, with animal and human data available; levamisole hydrochloride (levamisole), acetyl salicylic acid (ASA), thalidomide, erlotinib hydrochloride (erlotinib), anti-vascular endothelial growth factor (anti-VEGF), and 2-methoxyestradiol (2-ME). The relevance of the method to man was shown by comparing the obtained results to the literature data from the clinical studies with the same compounds. We here show that through thorough optimization and intra-laboratory pre-validation, it is possible to develop cell a culture assay into a reproducible and repeatable routine method with minimal variation and easy and fast semi-quantitative analysis of the effects.

\section{MATERIALS AND METHODS MATERIALS AND CHEMICALS}

The BJ human foreskin fibroblasts were purchased from American Type Culture Collection (ATCC, LGC Promochem AB, Boras, Sweden, Cat. No. CRL-2522, Lot No. 57632920). Fetal bovine serum (FBS, Cat. No. 10106), L-glutamine (Glu, Cat. No. 25030), non-essential amino acids (NEAA, Cat. No. 11140), and TrypLE Express (Cat. No. 12604) were obtained from Gibco, Invitrogen, Carlsbad, CA, USA. DAB Substrate Kit (Cat. No. 00-2014) was from Zymed Laboratories Inc, Invitrogen, Carlsbad, CA, USA. EGM-2 bullet kit including SingleQuotssupplements (Cat. No. CC-3162), endothelial basal medium (EBM; Cat. No. CC-3156), EGM-2 SingleQuots-supplements (Cat. No. CC-4176), Gentamicin sulfate $50 \mathrm{mg} / \mathrm{ml}$ (Cat. No. 17-518Z), and Amphotericin B $250 \mu \mathrm{g} / \mathrm{ml}$ (Cat. No. 17-836E) were obtained from Lonza Group Ltd., Basel, Switzerland. Recombinant Human Fibroblast Growth Factor-basic 146 AA (FGF-2, Cat. No. 233-FB, Lot. No. HKW3809032, ED 50 for inducing proliferation of NR6R-3T3 mouse fibroblasts is typically 0.1$0.6 \mathrm{ng} / \mathrm{ml}$ ) and Recombinant human vascular endothelial growth factor 165 (VEGF, Cat. No. 293-VE, Lot. No. II2209012, ED 50 for inducing proliferation of human umbilical vein endothelial cells (HUVEC) is typically 2.0-6.0 ng/ml) were obtained from R\&D Systems, Abingdon, UK. 1,4-Ditiotreitol (DTT, Cat. No. 233156, Molecular Biology Grade) was obtained from Calbiochem, San Diego, CA, USA. Bovine serum albumin fraction V (BSA, Cat. No. 107350940019) was from Roche, Indianapolis, IN, USA. Erlotinib (Lot. No. BS06110030) was a kind gift from Roche Diagnostics GmbH, Mannheim, Germany. Anti-von Willebrand Factor (AntivWf) antibody produced in rabbit (Cat. No. F-3520), Neutral Red (NR) Solution (Cat. No. N2889), anti-VEGF (Cat. No. V6627, Lot. No. 088K1260), thalidomide (Cat No. T144, Lot. No. 097K4601), levamisole (tetramisole hydrochloride, Cat. No. L9756, Lot. No. 088K0753), 2-ME (Cat. No. M6383, Lot. No.
108K4087), and ASA (Cat. No. A5376, Lot. No. 048K0015) were from Sigma Aldrich, Manassas, VA, USA. Biotinylated anti-rabbit IgG $(\mathrm{H}+\mathrm{L})$ made in goat (Cat. No. BA-1000) and Vectastain Elite ABC Kit, Standard (Cat. No. PK-6100) were purchased from Vector laboratories Inc, Burlingame, CA, USA. Triton X-100 was from JT Baker, Phillipsburg, NJ, USA. Collagenase I was purchased from Invitrogen, Paisley, Scotland, UK. A 75- $\mathrm{cm}^{2}$ filtered cell culture flasks (Nunc EasyFlask ${ }^{\mathrm{TM}}$ ) were from Nunc, Roskilde, Denmark. MycoAlert ${ }^{\circledast}$ Mycoplasma Detection Kit (LT07-118) was purchased from Lonza Group Ltd., Basel, Switzerland.

\section{POSITIVE AND NEGATIVE CONTROLS}

The tubule formation potency of each reference chemical was quantified based on the tubule formation potency of the positive control. The negative control compound induced no tubule formation. The positive control was a cocktail of commercial, well known angiogenic factors, VEGF, and fibroblast growth factor 2 (FGF $\beta$ or FGF-2), that are widely used to mimic the human tubule formation in vitro (Bishop et al., 1999; Cross and Claesson-Welsh, 2001; Donovan et al., 2001; Friis et al., 2003; Ai et al., 2007). The positive control medium consisted of $10 \mathrm{ng} / \mathrm{ml} \mathrm{VEGF}$ and $1 \mathrm{ng} / \mathrm{ml} \mathrm{FGF}-2$ dissolved in endothelial basal medium (EBM). The optimal positive control was chosen by testing different concentrations of VEGF and FGF-2 (Table 1). As the negative control compound, which induced no tubule formation, endothelial basal medium (EBM) without any growth factors was used. Negative control gave the same response as the solvent. Positive control was used in four parallels and negative control in two parallels throughout the procedure in each 48-well plate to ensure the technical validity of the tests. Additionally, the dimethyl sulfoxide (DMSO) control was used in three of the reference chemicals (thalidomide, erlotinib, and 2-ME) as they were dissolved in DMSO. DMSO concentration never exceeded $0.5 \%$.

\section{REFERENCE CHEMICALS}

The six reference chemicals and their concentrations used for pre-validation of an in vitro angiogenesis assay are shown in Table 2. The rationale behind selection of the reference chemicals were that they are consistent with the defined objectives of the study (known inhibitors of angiogenesis), they represent different types

Table 1 |The growth factor cocktails used in investigation of the optimal positive control, linearity, upper and lower limits and batch to batch variation.

\begin{tabular}{ll}
\hline Growth factor cocktail no. & $\begin{array}{l}\text { VEGF/FGF-2 } \\
\text { concentration }(\mathbf{n g} / \mathbf{m l})\end{array}$ \\
\hline 1 & $75 / 7.5$ \\
2 & $50 / 5.0$ \\
3 & $25 / 2.5$ \\
4 & $10 / 1.0$ \\
5 & $7.5 / 0.75$ \\
6 & $5.0 / 0.5$ \\
7 & $2.5 / .25$ \\
8 & $1.0 / 0.1$
\end{tabular}


Table 2 | Reference chemicals tested in the intra-laboratory pre-validation of an in vitro angiogenesis assay.

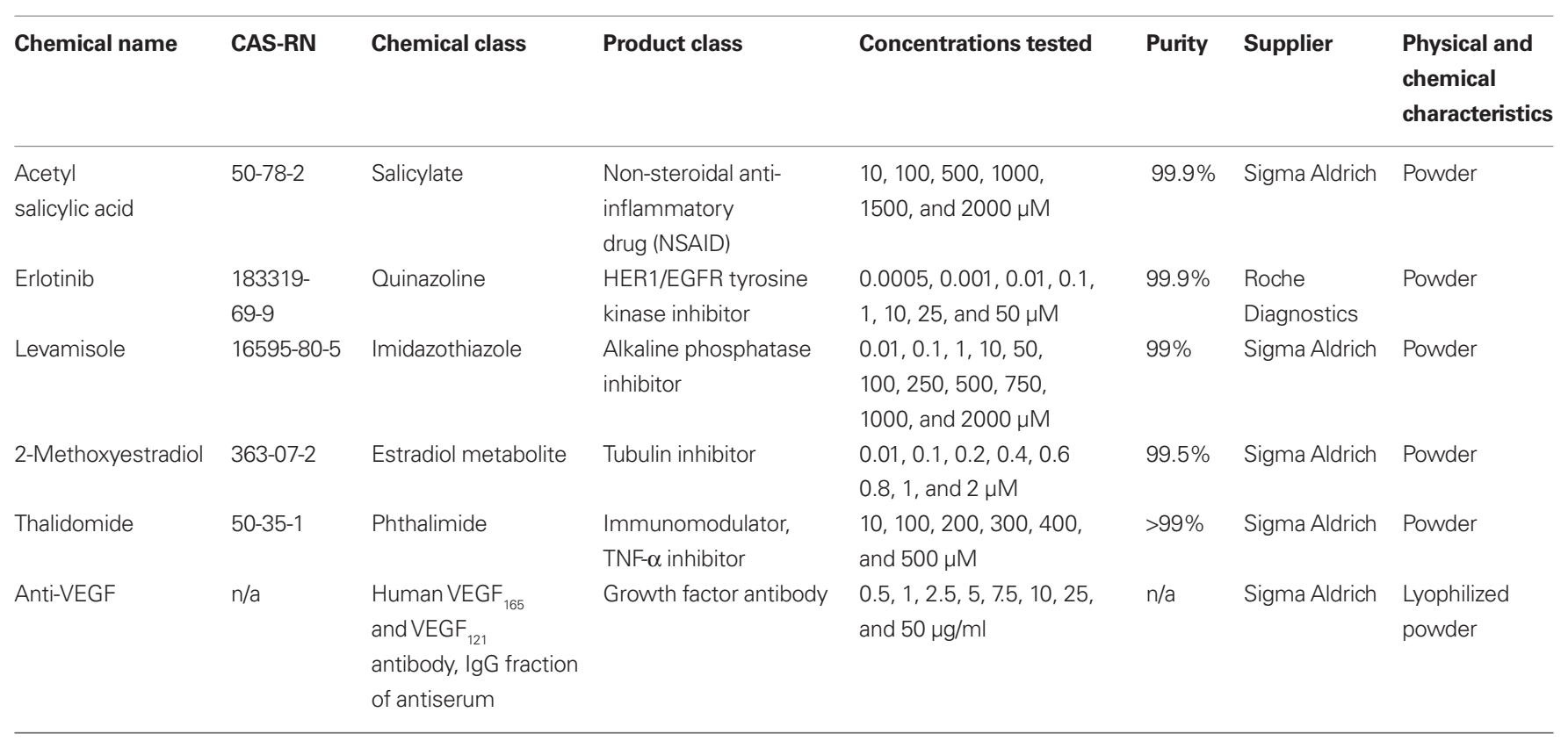

of chemicals and reliable and relevant reference data in animals and man is available. No other inducers of angiogenesis than the positive control were included. The concentration range for each chemical was selected prior to the angiogenesis assay. The criteria for the selection of the chemical were non-toxicity, solubility in the test system, and that DMSO concentration not exceeding $0.5 \%$ in the test system. Reference chemicals were dissolved according to manufacturer's instructions and further diluted in stimulation medium (=endothelial basal medium supplemented with $10 \mathrm{ng} / \mathrm{ml}$ VEGF and $1 \mathrm{ng} / \mathrm{ml} \mathrm{FGF-2)} \mathrm{prior} \mathrm{to} \mathrm{use.}$

These reference chemicals are widely studied angiogenesis inhibitors and pharmaceuticals. Anti-VEGF is the first angiogenesis inhibitor that has been approved by the U.S. Food and Drug Administration under trade name Avastin (bevacizumab) for the treatment of colon cancer (Folkman, 2006). According to Folkman (2006) VEGF antibody (trade name Lucentis) and aptamer of VEGF (trade name Macugen) are used for the treatment of macular degeneration; erlotinib (trade name Tarceva), an epidermal growth factor receptor (EGFR) tyrose kinase inhibitor is used for the treatment of lung cancer; thalidomide is used for the treatment of multiple myeloma. ASA has protective effects against colon cancer and cardiovascular disease (Yan et al., 2010). 2-ME is approved by FDA for the treatment of ovarian cancer under trade name Panzem. 2-ME has also been studied in the treatment of rheumatoid arthritis (Brahn et al., 2008), cardiovascular diseases (Dubey and Jackson, 2009), multiple myeloma (Rajkumar et al., 2007), breast cancer (Greenberg and Rugo, 2010), and prostate cancer (Harrison et al., 2010). Levamisole (trade name Ergamisol) has been used to treat worm infestations in both humans and animals and it is tested in clinical trials for the treatment of chronic idiopathic urticaria (Zhang et al., 2009), for colorectal cancer (Quasar Collaborative et al., 2007; Dahl et al., 2009), for malignant melanoma (Verma et al., 2006), and for malaria (Dondorp et al., 2007).

\section{METHODS}

\section{Setting up Master cell banks}

Quality control (QC) criteria for setting up Master cell banks were as follows: cell cultures were pure with high proliferation capacity and contained no mycoplasma. Cell viability was over $90 \%$. Cell culture was quality-controlled microscopically and always prior to Master cell bank establishment. The cells were tested for mycoplasma contamination with MycoAlert ${ }^{\circledast}$ Mycoplasma Detection Kit according to manufacturer's instructions. The cell lines (human foreskin fibroblasts) were not passaged over 10 times and the passaging of primary cells (HUVEC) was investigated and optimized. No antibiotics were used in cell culture.

Human foreskin fibroblasts. Human foreskin fibroblasts were obtained from ATCC and cultured in Minimum Essential Medium with Earle's salts, w/o L-Glutamine supplemented with 10\% FBS, $1 \%$ L-glutamine, $1 \%$ NEAA, and $1 \%$ antibiotic-antimycotic mixture in $75 \mathrm{~cm}^{2}$ cell culture flasks in $10 \mathrm{ml}$ of medium at $37^{\circ} \mathrm{C}$ in $5 \%$ $\mathrm{CO}_{2}$ incubator. The medium was changed and the cells observed microscopically for their morphology and cell proliferation every 3 days. When confluent, the cells were detached with Tryple Express and subcultured in a ratio of 1:9. The cells were cryopreserved in liquid nitrogen, 500000 cells per vial to create the Master cell bank.

Human umbilical vein endothelial cells. The human umbilical cords were obtained from scheduled cesarean sections with informed consent from Tampere University Hospital (permission No. R08028 from the Ethics Committee of the Pirkanmaa Hospital District, Tampere, Finland). The isolation of umbilical vein endothelial cells (HUVEC) from human umbilical cord veins was performed as described by Jaffe et al. (1973) but the process was further optimized. The umbilical cord was separated from the placenta and the umbilical vein was cannulated with a $20 \mathrm{G}$ needle. The needle was secured by clamping the cord over the needle with 
a surgical clamp. The vein was perfused with Umbilical cord buffer solution (UBS; $0.1 \mathrm{M}$ phosphate buffer solution containing $0.14 \mathrm{M}$ $\mathrm{NaCl}, 0.004 \mathrm{M} \mathrm{KCl}$, and $0.011 \mathrm{M}$ glucose) to wash out blood after which the other end of the umbilical vein was clamped with a surgical clamp. The vein was infused with $0.05 \%$ collagenase I. The umbilical cord was incubated in a water bath at $37^{\circ} \mathrm{C}$ for up to $20 \mathrm{~min}$. After incubation, the collagenase solution containing HUVEC was flushed from the cord by infusing the vein with UBS. The suspension was flushed out into a $50-\mathrm{ml}$ polypropylene tube. The cells were centrifuged at $250 \times g$ for $10 \mathrm{~min}$, resuspended in EGM-2 BulletKit medium, seeded into $75 \mathrm{~cm}^{2}$ filtered cell culture flasks, and cultured at $37^{\circ} \mathrm{C}$ in $5 \% \mathrm{CO}_{2}$ incubator.

The isolated HUVEC were daily observed microscopically for their morphology, cell culture purity, and cell proliferation. The medium was changed every 2-3 days. When confluent, the cells were detached with Tryple Express. Pure HUVEC cultures with good proliferation capacity were subcultured at primary culture (p0) in the ratio of 1:2-1:4 and at passages 1 (p1) upward in a ratio of 1:3-1:5. The isolated HUVEC were tested for their tubule formation capacity in the angiogenesis assay up to passage 10. At passage 2 (p2), the cells were cryopreserved in liquid nitrogen, 500000 cells per vial to create the Master cell bank. The donor-specific batch number was given to each batch stored in the Master cell bank.

\section{Co-culture establishment}

BJ fibroblasts were taken from the Master cell bank, thawed, and cultured as above (see Human Foreskin Fibroblasts) for 3 days. On day 3 , the BJ fibroblasts were plated into 48 -well plates at a cell density of 20000 cells $/ \mathrm{cm}^{2}$, and grown for an additional 3 days. On day 3 , the HUVEC were taken from the Master cell bank, thawed, and cultured as above (see Human Umbilical Vein Endothelial Cells), separately from BJ fibroblasts, for 3 days. On day 6, the HUVEC cells were carefully seeded on the top of BJ fibroblasts into 48-well plates at a cell density of 4000 cells $/ \mathrm{cm}^{2}$. The co-culture was then further used for cytotoxicity test and for angiogenesis assay.

\section{Cytotoxicity test}

To find out the highest concentration for each reference chemical for the angiogenesis assay, a cytotoxicity test was performed. Both technicians performed individually the cytotoxicity test for each reference chemical. As the cytotoxicity assay, the neutral red uptake (NRU) cell viability assay was used. The co-culture of fibroblasts and HUVEC was first established as described above (see Co-Culture Establishment). Twenty-four hours after co-culture establishment, the test system was treated by exposing with positive or negative controls (see Positive and Negative Controls), or reference chemicals (see Reference Chemicals and Table 1) for $24 \mathrm{~h}$. After exposure for $24 \mathrm{~h}$, the exposure medium was removed and the cells were washed with preheated PBS. Two hundred fifty microliters of NR-medium (25 mg NR/1 ml medium) was added into the wells and incubated for $2 \mathrm{~h}$ at $37^{\circ} \mathrm{C}$. After incubation, NR-medium was removed and the cells were washed with $250 \mu \mathrm{PBS}$. After that, $100 \mu \mathrm{l} \mathrm{NR}$-desorption medium ( $50 \%$ EtOH, $1 \%$ acetic acid in $\mathrm{H}_{2} \mathrm{O}$ ) was added into the wells and incubated in a shaker for $20 \mathrm{~min}$, protected from light. After shaking, the cells were allowed to settle down for $5 \mathrm{~min}$. The absorbance was measured at $540 \mathrm{~nm}$ with Thermo Scientific Varioskan Flash Spectral Scanning Multimode Reader (Thermo Fisher Scientific Inc., Waltham, MA, USA).

\section{Angiogenesis assay}

The angiogenesis assay was performed independently by two technicians and two analysts. The technicians performed the whole assay independently, except that the microscopic analysis was performed independently and blinded by two analysts. For microscopic analysis the samples were coded by a person not directly involved in the study.

The co-culture of fibroblasts and HUVEC was first established as described above (see Co-Culture Establishment). The day after co-culture creation, the co-culture was exposed to the positive or negative controls (see Positive and Negative Controls), the reference chemical treatments (see Table 1) or growth factor cocktails (see Table 2). The cells were cultured at $37^{\circ} \mathrm{C}$ for 6 days prior to immunocytochemical staining. The media containing either reference chemicals, or growth factor cocktail, or positive control or negative control, were changed once during the assay, on the third day.

Immunocytochemical staining. At day 6 from the onset of the experiment, the tubules were immunostained with anti-vWF. The media were removed and the cells were washed three times with PBS, fixed with ice-cold 70\% ethanol for $20 \mathrm{~min}$, permeabilized with 0.5\% Triton X-100 (JT Baker, Phillipsburg, NJ, USA) for $15 \mathrm{~min}$ and blocked for unspecific staining with 10\% BSA (Roche Diagnostics Corporation, Indianapolis, IN, USA) for 30 min. After blocking, the cells were incubated with primary antibody (anti-vWf, 1:5000) at $4^{\circ} \mathrm{C}$ overnight or for $1-2 \mathrm{~h}$ in room temperature (RT). Cells were then washed three times with PBS, incubated for 30 min with the secondary antibody (biotinylated anti-rabbit IgG, $\mathrm{H}+\mathrm{L}$ made in goat) and washed again three times with PBS. The cells were then incubated with enzyme conjugate solution (Vectastain Elite ABC Kit) for $30 \mathrm{~min}$, after which substrate was added (DAB Substrate Kit). The color development was followed under microscope for 5-10 min and the reaction was stopped with $0.5 \mathrm{M}$ Tris buffer. After staining, $500 \mu \mathrm{l}$ of Tris buffer was pipetted into each cell culture well and the plates were sealed with parafilm for storage at $4^{\circ} \mathrm{C}$ until microscopic analysis.

Microscopic analysis. After immunocytochemical staining, the tubules were analyzed with Nikon Eclipse TS100 microscope (Nikon, Tokyo, Japan). The extent of tubules and their branching was quantified using predetermined visually inspected semiquantitative grading scale from 0 to 8 . The analysis and grading required expertise and therefore were performed by scientists. As the microscopic analysis was based on semi-quantitative visual analysis, we especially wanted to test the repeatability of the analysis. Therefore all plates and wells were coded and analyzed individually by two scientists. Figure 1 shows the tubule network formation from negative and positive control.

Statistics. One-way analysis of variance with Dunnett's post test was used for the statistical analysis of the reference chemical results. The linearity of tubule formation was tested with linear regression and precision with coefficient of variation (CV). The day to day variation of technicians was tested with one-way analysis of variance, person to person variation between technicians with unpaired $t$-test and person to person variation between 


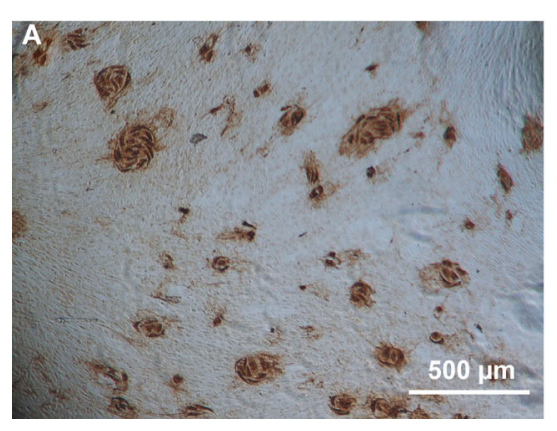

FIGURE 1 |Angiogenesis in vitro assay. The BJ fibroblast HUVEC co-culture was immunostained with anti-vWf antibody (1:5000) and with DAB Substrate kit. (A) Negative control, no tubule development (value 0 in tubule formation grading). Endothelial cells remain as epithelial-like round areas in co-culture.

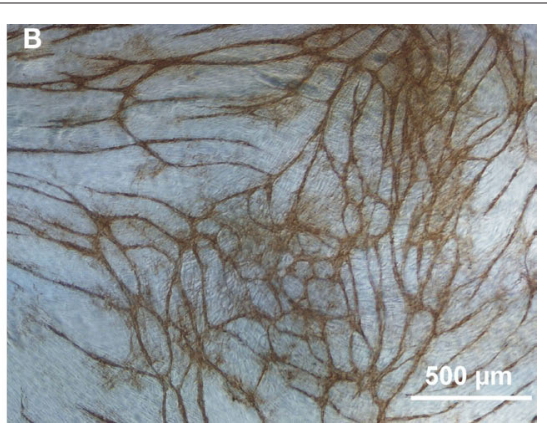

(B) Positive control (cocktail of $10 \mathrm{ng} / \mathrm{ml} \mathrm{VEGF} \mathrm{and} 1 \mathrm{ng} / \mathrm{ml} \mathrm{FGF-2)} \mathrm{inducing} \mathrm{tubule}$ network formation (value 7 in tubule formation grading). Cells form tubule-like structures connecting to each other. Extensive branching of cells and long structures that cover the whole area of the well. Scale bar $500 \mu \mathrm{M}$. analysts with paired $t$-test. All statistical analyses were performed using GraphPad Prism 5.0 (GraphPad Software Inc., La Jolla, CA, USA).

\section{TEST ACCEPTANCE CRITERIA \\ Technical criteria}

Three wells of the positive control had to give values 6-7 at each testing time. One well could give value 5 . Then, the calculated minimum value for positive control is 5.75 . The negative control had to be always negative ( 0 ). Only one out of two parallels in one combination of each reference chemical during each testing time could be discarded based on visual inspection in case the cells were found to be dead or detached.

\section{Sensitivity of detection}

For sensitivity of detection, linearity as well as upper and lower limits of detection, were investigated. Eight different growth factor cocktail concentrations (VEGF and FGF-2, 10:1) were used (Table 1) and investigated in order to find the optimal cocktail for positive control.

Linearity. Linearity was tested in order to find out the growth factor cocktail concentration range that induces tubule formation in a linear manner. For linearity testing, the negative control, and different growth factor cocktails (VEGF and FGF-2, 10:1) were used (see Table 1). Each cocktail was tested in six parallels.

Upper and lower limits of detection. The dose-response effect of the growth factor cocktails were investigated, and the combination of growth factors (see Table 1 for the growth factor cocktails used) giving the maximum value in the linear part of the response curve was selected to be the upper limit of detection. This was also chosen as the fixed positive control for the test (see Positive and Negative Controls). For the lower limit of detection, the growth factor cocktail that gives value 1 in the linear range of the tubule formation scale was selected. Each cocktail was tested in six parallels.

\section{Batch to batch variation}

Testing of the batch to batch variation between different HUVEC batches (different umbilical cords, i.e., donor samples) was performed to confirm that each of the Master cell bank batches set up in our laboratory gives comparable results. The batch to batch variation testing was performed in the angiogenesis assay with the growth factor cocktails shown in Table 1. Three HUVEC batches of passage 4 with 6 parallels were investigated. All of the batches had to follow the criteria for upper and lower limits of detection and to follow linearity.

\section{Precision}

To find out the maximal variation due to technicians and microscopic analysts, two technicians performed the positive and negative control tests (each technician performed one 48-well plate of negative control and one 48 -well plate of positive control). The negative control was tested in the angiogenesis assay with endothelial basal medium (EBM) without any growth factors. The positive control was tested in the angiogenesis assay with one VEGF and FGF-2 dilution, i.e., positive control (10 ng/ml VEGF and $1 \mathrm{ng} / \mathrm{ml} \mathrm{FGF-2).}$ Total variation in the test had to be $\leq 15 \%$ analyzed with CV. It is known, that cell culture conditions may be affected by the position of the well in the plate. Therefore, the whole plate was used to test the maximal variation including technicians, microscopic analysts, and cell culture conditions within plate.

\section{Reliability}

To test the reliability, two technicians repeated the test three times in unchanged conditions for all the reference chemicals. Reliability included repeatability, i.e., the positive control and the reference chemicals must give comparable results regardless of the testing time, and reproducibility, i.e., the effect of each reference chemical must be the same regardless of the technician. The positive control included altogether 24 parallels performed at three consecutive days by two technicians and each testing time included four parallels. The positive control contained four parallels and was always placed at the same position in a 48 -well plate.

Repeatability. The test was performed by two technicians - microscopic analyst - pairs three times using identical protocol (day to day variation).

Reproducibility. Two technician - microscopic analyst - pairs repeated the same identical test protocol (person to person variation). In addition, each analyst analyzed all plates. 


\section{Performance}

The overall performance of the assay was tested by repeating the identical protocol with six different reference chemicals three times by two technician - microscopic analyst - pairs.

\section{TEST METHOD DATA QUALITY}

All work was performed according to the Good Laboratory Practice Regulations as set forth in OECD [ENV/MC/CHEM (98)17], in accordance with OECD guidelines [OECD Guidance document on the Validation and international Acceptance of New or Updated Test Methods for Hazard Assessment (OECD, 2005, No 34) and CPMP/ ICH/281/95] and ECVAM (European Centre for the Validation of Alternative Methods) guidance documents (http://ecvam.jrc.it/) and according to the standard operating procedures of FICAM.

\section{RESULTS}

\section{PRIMARY HUVEC MASTER CELL BANK OPTIMIZATION}

The tubule formation potency of HUVEC ( treated with the positive control) was studied up to passage 10 . The results of the passage optimization are seen in Figure 2. It was seen that up to passage 4

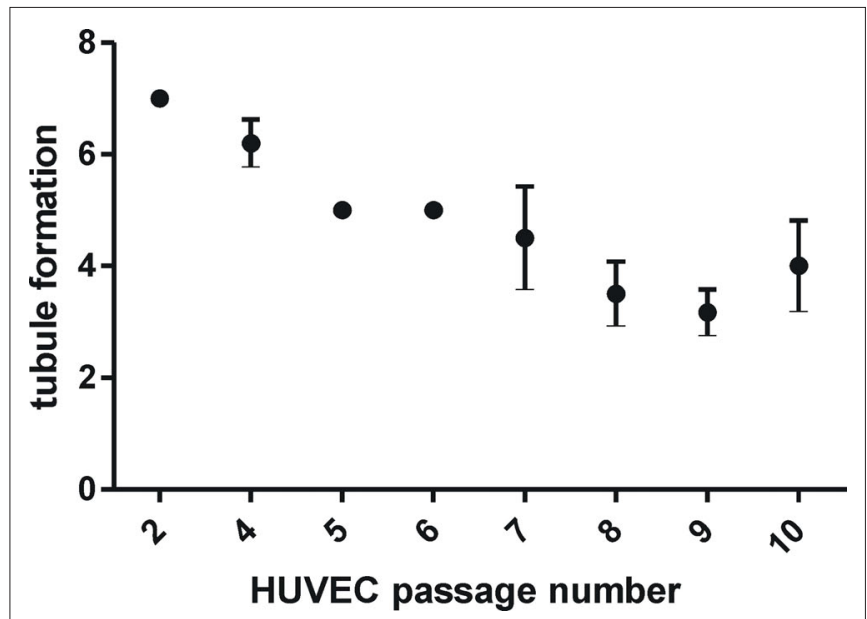

FIGURE 2 |Tubule formation potency of the positive control in the angiogenesis assay at different HUVEC passages. The results are given as mean \pm SD. The results are averages of at least three separate experiments. the tubule formation remained quite constant and high. During cultivation, when the passage number increased, the tubule formation decreased. Thus, the passage 4 was chosen as the fixed passage to be used in the angiogenesis assay.

\section{CYTOTOXICITY TEST}

The concentration giving the viability of $80 \%$ or higher was taken as the highest concentration to be used in the angiogenesis assay. Consequently, the concentration ranges were as follows: levamisole 0.01-2000 $\mu \mathrm{M}$, thalidomide $10-500 \mu \mathrm{M}$, erlotinib $0.0005-50 \mu \mathrm{M}$, 2-ME 0.01-2 $\mu \mathrm{M}$, and anti-VEGF 0.5-50 $\mu \mathrm{g} / \mathrm{ml}$. Only ASA showed toxicity. The toxicity was found at $2000 \mu \mathrm{M}$. Therefore the concentration range for ASA used in angiogenesis assay was $10-1500 \mu \mathrm{M}$.

\section{ANGIOGENESIS ASSAY \\ Technical validity of the test}

Positive control in each testing time gave the values 6-7 from 3 out of 4 parallels. Negative control always gave 0 . No wells needed to be discarded.

\section{Intra-laboratory pre-validation parameters}

Sensitivity of detection. The sensitivity of detection was evaluated by studying linearity and the upper and lower limits of detection. Figure $3 \mathrm{~A}$ shows the results obtained with HUVEC in the angiogenesis assay (three batches). The response was linear up to the growth factor cocktail of $10 \mathrm{ng} / \mathrm{ml} \mathrm{VEGF}$ and $1 \mathrm{ng} / \mathrm{ml} \mathrm{FGF-2} \mathrm{with} \mathrm{all} \mathrm{three}$ batches. At cocktails with higher growth factor concentrations, the response decreased. The growth factor cocktail that caused maximal tubule formation in the linear part of the response curve was a combination of $10 \mathrm{ng} / \mathrm{ml}$ VEGF and $1 \mathrm{ng} / \mathrm{ml} \mathrm{FGF}-2$ (Figure 3B) and was the upper limit of detection. This combination was also chosen as the fixed positive control for the test (see Positive and Negative Controls). The lowest VEGF and FGF-2 cocktail combination that induced tubule formation (value 1 in microscopic analysis of tubule formation grading) was found to be a combination of $1 \mathrm{ng} / \mathrm{mlVEGF}$ and $0.1 \mathrm{ng} / \mathrm{ml} \mathrm{FGF-2.} \mathrm{This} \mathrm{was} \mathrm{the} \mathrm{lower} \mathrm{limit} \mathrm{of} \mathrm{detection.}$

Batch to batch variation. The batch to batch variation was tested between three HUVEC batches treated with positive control (each batch with six parallels). The results are shown in Table 3. It was
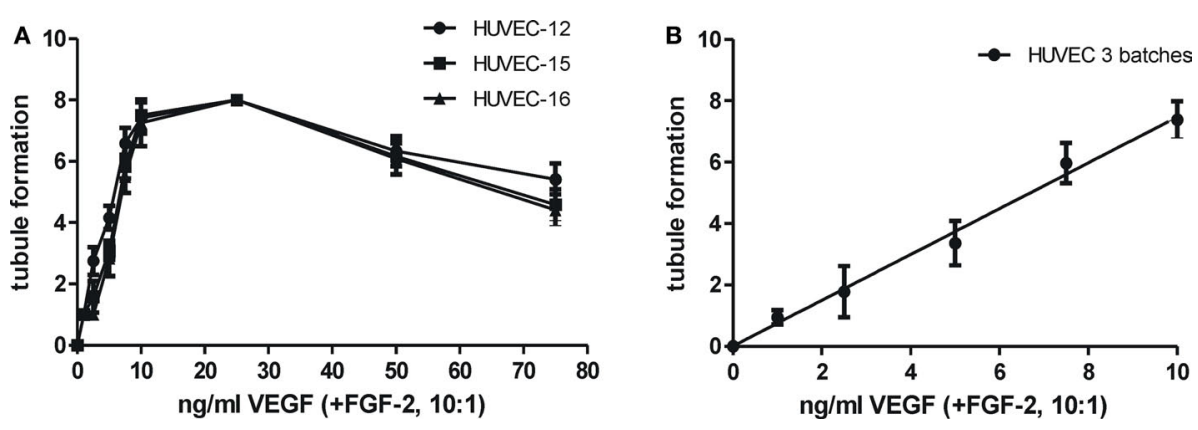

FIGURE 3 | (A) Upper and lower limits of detection of tubule formation for three different HUVEC batches (HUVEC-12, HUVEC-15, HUVEC-16, $n=12$ in each curve; (B) the linearity of tubule formation as tested from three different HUVEC batches with linear regression ( $n=36$ ). The growth factor concentrations are shown as VEGF concentrations. The concentrations of VEGF and FGF-2 used are seen in detail in Table 2. VEGF/FGF-2 ratio was always 10:1. The results are given as mean $\pm \mathrm{SD}$. 
seen, that the criteria for positive control value were met with all batches and that the variation between the batches was extremely small $(\mathrm{CV}=1.72 \%)$.

Precision. To find out the maximal variation, including that caused by technicians and microscopic analysts, the angiogenesis assay with positive and negative controls was performed. The results of the positive and negative control and their CV\% are shown in Table 4. Negative control was always found to give the value 0 however; the CV\% of positive control was found to be between 6.27 and $7.82 \%$.

\section{Reliability}

Repeatability. The results of day to day variation between technicians and microscopic analysts are presented in Table 5. No significant differences were observed among technicians $(p=0.906$ and $p=0.064$ ). The microscopic analyst-technician pairs had following day to day variation: microscopic analyst 1 technician $1 \mathrm{CV}=0.59 \%$, microscopic analyst 2 technician $1 \mathrm{CV}=0.67 \%$, microscopic analyst 1 technician $2 \mathrm{CV}=6.38 \%$. Microscopic analyst 2 technician $2 \mathrm{CV}=5.02 \%$. We further studied whether the variation was due to analysis or due to technical performance (see Reproducibility).

Reproducibility. When the person to person variation was studied, each analyst analyzed all plates. Overall there was only a minor difference in $\mathrm{CV} \%$ between technicians [the results of technician 1 or technician 2 were analyzed by both (two) analysts], being $0.64 \%$ with technician 1 and $5.63 \%$ with technician 2 . The person to person variation is seen in Table 5. The results showed that the CV\% between microscopic analysts was very low; CV\% was $0.34 \%$

Table 3 | Batch to batch variation in tubule formation between three HUVEC batches (HUVEC-12, HUVEC-15, HUVEC-16, $n=12$ with each batch).

\begin{tabular}{lllll}
\hline & Criteria & HUVEC-12 & HUVEC-15 & HUVEC-16 \\
\hline $\begin{array}{l}\text { Positive control } \\
\text { (mean) }\end{array}$ & $\geq 5.75$ & 7.417 & 7.500 & 7.250 \\
$\begin{array}{l}\text { Mean (three } \\
\text { batches) }\end{array}$ & $\geq 5.75$ & & 7.389 & \\
Variation (CV\%) & $\leq 15 \%$ & $1.72 \%$ & \\
\hline
\end{tabular}

CV\%, coefficient of variation (\%). when the results of technician 1 were analyzed and $2.37 \%$, when the results of technician 2 were analyzed. No statistically significant difference ( $p=0.2084$ ) was observed between the analysts. When comparing the technicians to each other (person to person variation), a statistically significant difference was observed ( $p=0.007)$, whereas no person to person variation between analysts was seen However, the total CV, i.e., the total variation in the assay was as low as $\mathrm{CV}=1.39 \%$.

\section{Performance}

The performance of the assay was assessed by six different reference chemicals with several concentrations of each. The results of the effects of reference chemicals on tubule formation are seen in Figure 4. All the reference chemicals inhibited tubule formation as expected. Although the response was reference chemical specific, the phenomenon was repeatable, and variation remained constant throughout the study. The tubule inhibition was calculated to be mild (20\% inhibition from positive control), moderate (40-60\% inhibition from positive control or strong (75-85\% inhibition from control). The severity of inhibition and the concentrations causing mild, moderate, or strong inhibition are summarized in Table 6, where the reference chemical results of our in vitro assay are compared to other in vitro angiogenesis test methods, to the relevant plasma concentrations in clinical studies and to effective doses from animal studies.

\section{DISCUSSION}

The present intra-laboratory pre-validation study showed that a standardized in vitro angiogenesis assay is reliable and reproducible for testing the modulators of angiogenesis, and this human primary cell based in vitro assay mimics well the effects in man. Thus, it has great potency to supplement and/or replace animal tests.

Appropriately pre-validated human cell in vitro assays are urgently needed for reducing and replacing animal tests. In vitro angiogenesis assays are regarded as useful tools for screening compounds and their effective concentrations, but due to complex interactions during angiogenesis, they often need to be followed by in vivo studies (Auerbach et al., 2003). Animal assays, although not necessarily predictive for effects in human, are widely used as they provide information on complex cellular and molecular interactions (Norrby, 2006). The disadvantages of the current in vitro assays are that they lack metabolism and are rarely completely based on human biology (Auerbach et al., 2003).

Table 4 |The precision of the in vitro angiogenesis assay. Maximal variation in the angiogenesis assay was tested with positive and negative controls (Two pairs of microscopic analyst-technician performing each one 48-well plate of negative control and one 48-well plate of positive control).

\begin{tabular}{|c|c|c|c|c|c|}
\hline & Criteria & $\begin{array}{l}\text { Technician } \\
\text { 1-microscopic } \\
\text { analyst } 1\end{array}$ & $\begin{array}{l}\text { Technician } \\
\text { 1-microscopic } \\
\text { analyst } 2\end{array}$ & $\begin{array}{l}\text { Technician } \\
\text { 2-microscopic } \\
\text { analyst } 1\end{array}$ & $\begin{array}{l}\text { Technician } \\
\text { 2-microscopic } \\
\text { analyst } 2\end{array}$ \\
\hline Negative control & 0 & 0 & 0 & 0 & 0 \\
\hline Variation (CV\%) & $\leq 15$ & 7.61 & 6.27 & 6.85 & 7.82 \\
\hline
\end{tabular}

CV\%, coefficient of variation (\%). 
Table 5 | Day to day variation (repeatability) and person to person variation (reproducibility) between the technicians and the microscopic analysts. Criteria set and the positive control values obtained.

Reproducibility and repeatability

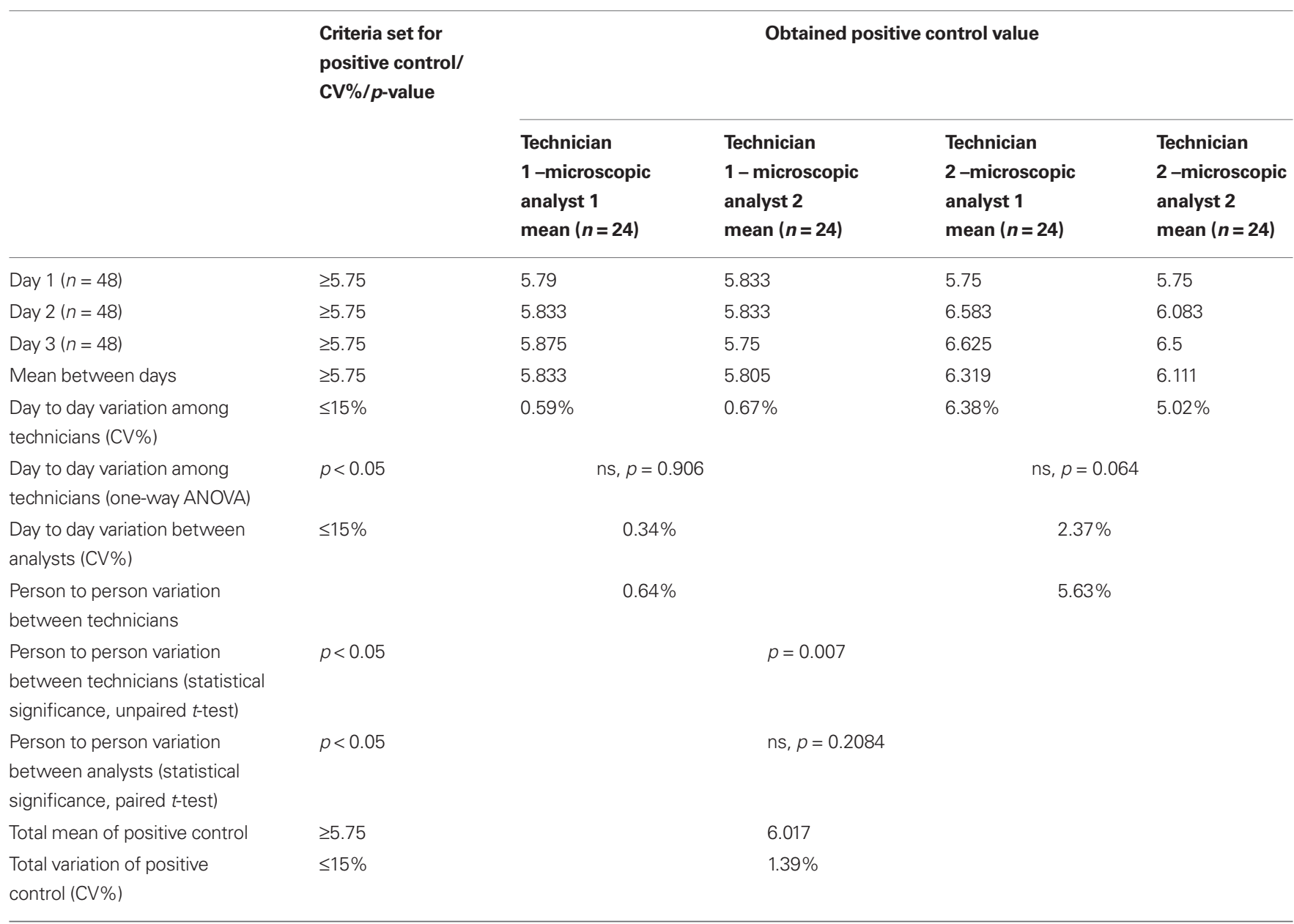

$C V$, coefficient of variation, ns, non-significant

We further developed, optimized and finally intra-laboratory pre-validated the previously published angiogenesis assay (Bishop et al., 1999). Our assay is based on quality-controlled primary HUVEC that have been minimally expanded in vitro. The optimization of the HUVEC passage number was found to be one crucial factor for the adequate performance of the assay. The tubule formation ability decreased significantly after serial passaging. Based on the optimization phase, the use of one, fixed passage of HUVEC was found to be optimal. This shows, that the effect of passage number on the biological activity of cells has to be investigated and the passage number fixed in order to maintain repeatability of the assay. Through optimization, we could obtain a routine assay with minimal variation (overall CV\% between the two technicians and microscopic analysts was 1.39\%). However, statistically significant difference was found between technicians. The effect of this on the final results is avoided by using positive and negative controls as there was no significant difference in day to day variation among technicians. They are used to calculate the response of unknown substances, as well as used as internal controls in the assay.
The optimal positive control concentration, i.e., VEGF/FGF-2 growth factor cocktail was obtained by investigating the biological response of several growth factor concentrations in several HUVEC batches. The positive control optimization resulted in stable and repeatable effect. The batch to batch variation for HUVEC was minimal due to the optimized passage and pre-set QC criteria for the cells stored in Master cell bank. Moreover, the test duration was shortened from previous methods (Bishop et al., 1999; Donovan et al., 2001) from 14 to 6 days of co-culture and the assay setup was optimized for 48 -well plate to minimize the use of cells and to increase the capacity. A semi-quantitative microscopic analysis method, based on tubule formation, their connections and the complexity of the developed network, was developed. The prerequisite for the semi-quantitative grading was that the analysis covered the whole area of each well, contrary to the method of Bishop et al. (1999), where images taken from only five random fields in larger wells (24-well plates) were analyzed by computer analysis program. In optimization phase, the performance assay was tested with 19 reference chemicals; 

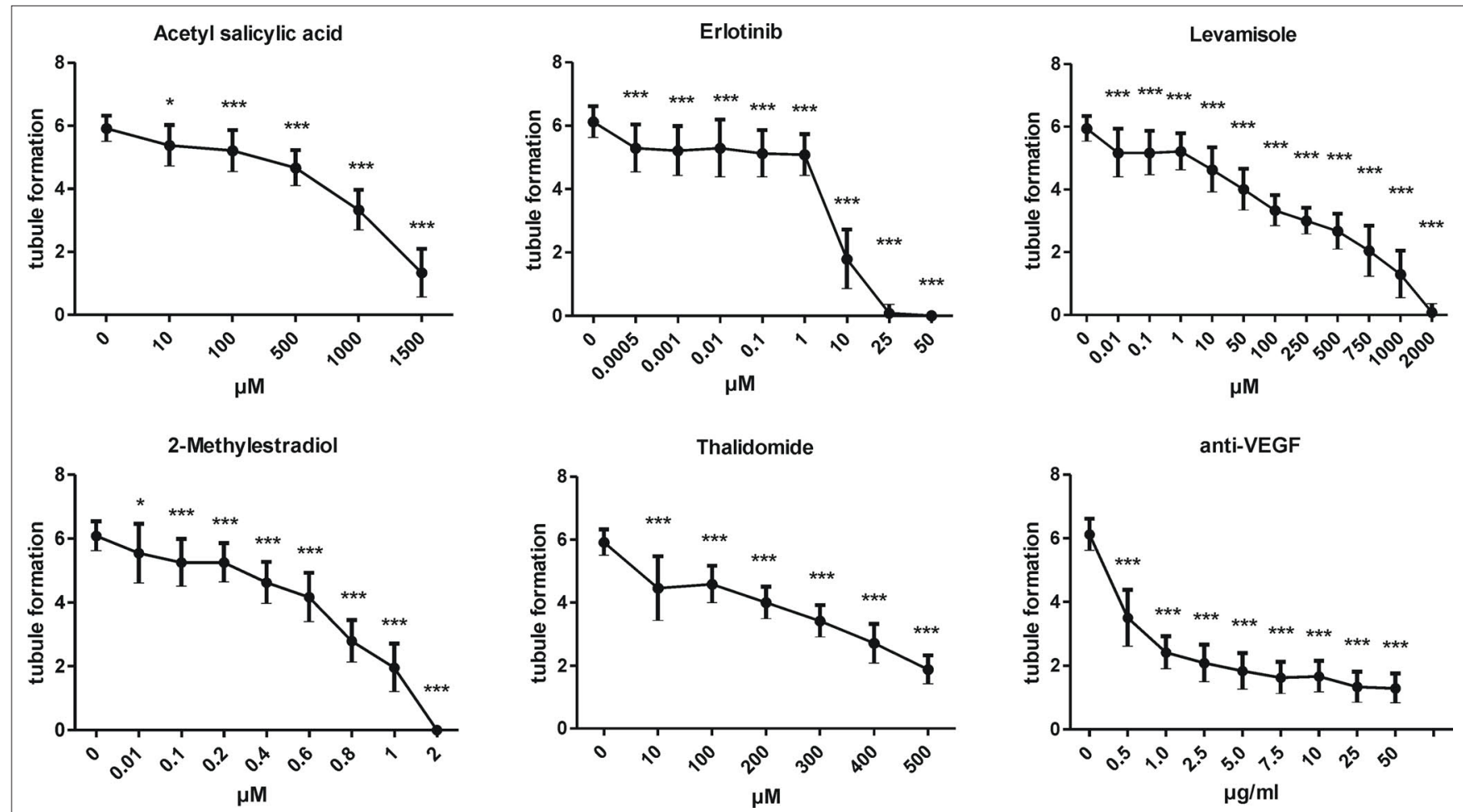

FIGURE 4 |The performance of the assay. The effects of the reference chemicals on tubule formation. The results are given as mean $\pm \mathrm{SD}, n=24$ including three testing times with two technicians. Microscopic analysis of all wells was performed individually by two analysts. The results were tested statistically by using one-way ANOVA with Dunnett's post test. ${ }^{*} p<0.05$, ${ }^{* *} p<0.01$ and ${ }^{* *} p<0.001$. endostatin, interleukin-1 soluble receptor 1 (IL-1 SR1), suramin, mevinolin, paclitaxel, fumagillin, anti-epidermal growth factor receptor (anti-EGFR) cyclooxygenase-2-specific inhibitor NS-398, indomethacin, VEGF, anti-VEGF, FGF-2, anti-FGF-2, platelet-derived growth factor beta (PDGF-BB), levamisole, erlotinib, ASA, 2-ME, and thalidomide.

The performance of the in vitro angiogenesis assay was proven in intra-laboratory pre-validation with six different reference chemicals (levamisole, ASA, thalidomide, erlotinib, anti-VEGF, and 2-ME). The obtained results were compared to the published data from other in vitro angiogenesis assays (Table 6). The table shows that comparable results were detected with ASA (Borthwick et al., 2006), with erlotinib (Birle and Hedley, 2006; Jimeno et al., 2007), and with 2-ME (Dobos et al., 2004). However, 2-ME had previously shown low inhibition at $10 \mu \mathrm{M}$ and moderate inhibition at $50 \mu \mathrm{M}$ (Kang et al., 2006), whereas our assay showed low and moderate inhibition at 0.01-0.2 and $1 \mu \mathrm{M}$, respectively. Moreover, compared to the method by Friis et al. (2003, 2005), which is a similar assay to ours, levamisole was reported to have mild inhibition at $500 \mu \mathrm{M}$ (in our study 0.01-1 $\mu \mathrm{M}$ ), moderate at $750-1000 \mu \mathrm{M}$ (in our study $100-$ $500 \mu \mathrm{M}$ ), and strong at $2000 \mu \mathrm{M}$ (in our study $1000-2000 \mu \mathrm{M}$ ). The anti-VEGF was reported to have moderate to strong inhibition at $0.1-10 \mathrm{mg} / \mathrm{ml}$ in an in vitro model with different study setup (Sims et al., 2008) compared to our assay (inhibition at $0.5-50 \mu \mathrm{g} / \mathrm{ml}$ ). There are known to be marked differences in tubule formation depending on the in vitro angiogenesis assay used (Donovan et al., 2001; Auerbach et al., 2003). However, compared to several previous in vitro studies, our assay shows improvement of sensitivity.

The relevance of the assay to man was investigated by comparing the obtained reference chemical results with data from clinical studies. The effective concentrations observed in our assay showed very good concordance with the respective therapeutic plasma concentrations (Table 6). The plasma concentrations of anti-VEGF obtained from different clinical trials varied extensively. One explanation is that the endogenous plasma concentrations of VEGF and FGF-2 differ among individuals and are also dependent on the disease (Kakimoto et al., 2002).

In conclusion, we here show that through thorough optimization, it is possible to develop a cell culture assay into a reproducible and repeatable routine method with minimal variation and with easy and fast semi-quantitative quantification of the end points. The intra-laboratory pre-validation study was completed successfully, the test was technically accepted and the pre-set acceptance criteria were met. In comparison of the results to the data from clinical trials shows that this human cell based in vitro angiogenesis assay mimics very well the effects in man, and thus it can be used to replace and/or supplement animal tests when testing angiogenesis modulators. The applicability domain contains so far pharmaceuticals. In addition to the chemical testing, the method has potency to test conditioned media of cells or even the effect of different cells (normal or cancer cells) with regard to their effect on angiogenesis. 
Table 6 |The comparison of the results from intra-laboratory pre-validated assay to the results from other in vitro methods, clinical studies and animal models.

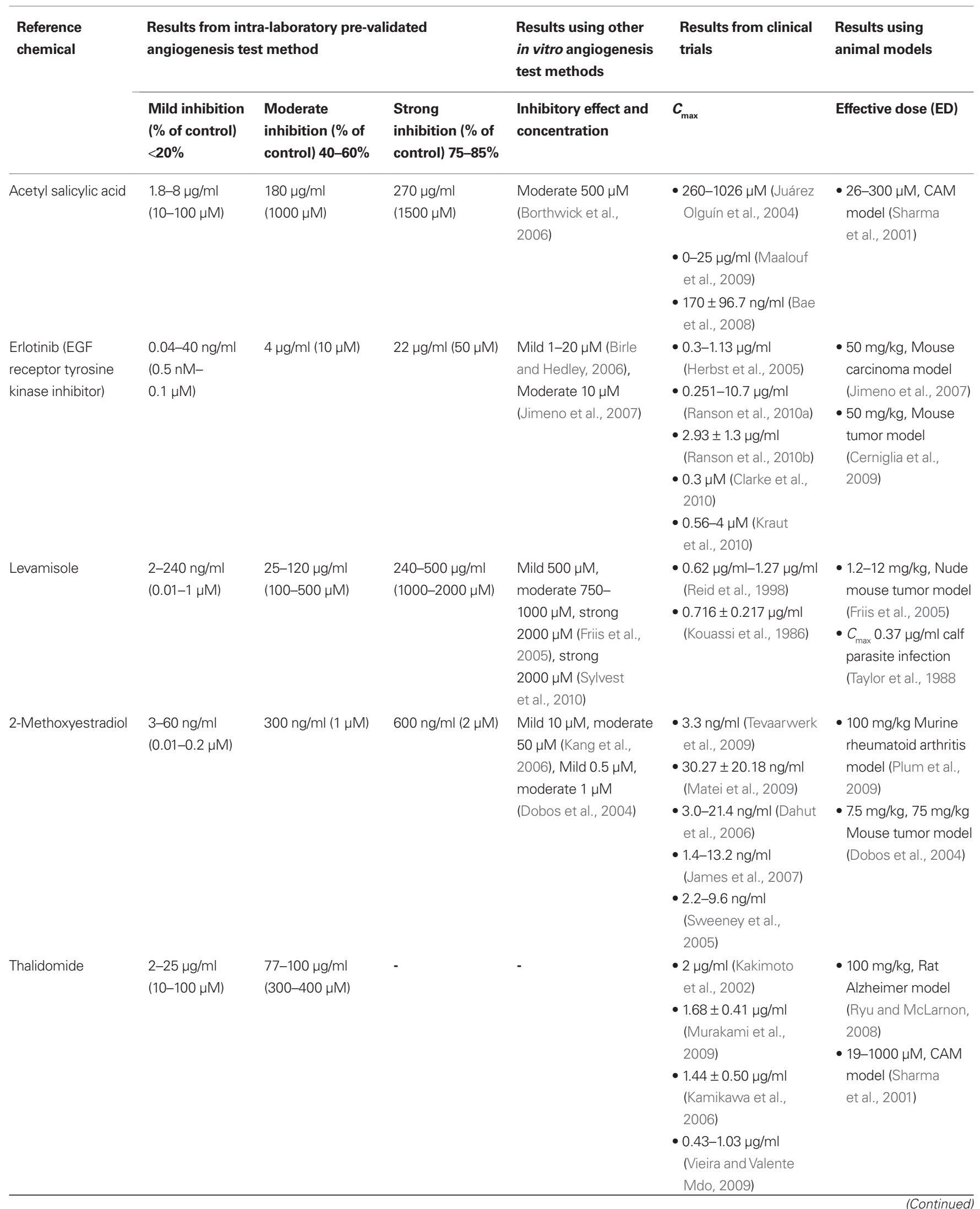




\begin{tabular}{|c|c|c|c|c|c|c|}
\hline \multirow[t]{2}{*}{$\begin{array}{l}\text { Reference } \\
\text { chemical }\end{array}$} & \multicolumn{3}{|c|}{$\begin{array}{l}\text { Results from intra-laboratory pre-validated } \\
\text { angiogenesis test method }\end{array}$} & \multirow{2}{*}{$\begin{array}{l}\text { Results using other } \\
\text { in vitro angiogenesis } \\
\text { test methods } \\
\text { Inhibitory effect and } \\
\text { concentration }\end{array}$} & \multirow{2}{*}{$\begin{array}{l}\text { Results from clinical } \\
\text { trials } \\
C_{\max }\end{array}$} & \multirow{2}{*}{$\begin{array}{l}\text { Results using } \\
\text { animal models } \\
\text { Effective dose (ED) }\end{array}$} \\
\hline & $\begin{array}{l}\text { Mild inhibition } \\
\text { (\% of control) } \\
<20 \%\end{array}$ & $\begin{array}{l}\text { Moderate } \\
\text { inhibition ( } \% \text { of } \\
\text { control) } 40-60 \%\end{array}$ & $\begin{array}{l}\text { Strong } \\
\text { inhibition ( } \% \text { of } \\
\text { control) } 75-85 \%\end{array}$ & & & \\
\hline Anti-VEGF & $0.01-0.1 \mu \mathrm{g} / \mathrm{ml}$ & $0.5-1 \mu \mathrm{g} / \mathrm{ml}$ & $25-50 \mu \mathrm{g} / \mathrm{ml}$ & 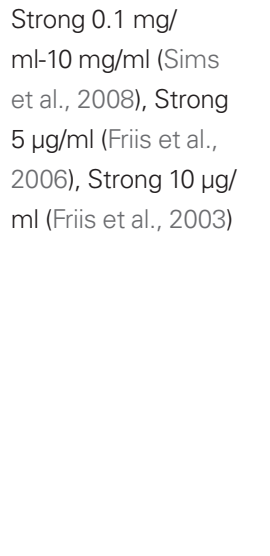 & 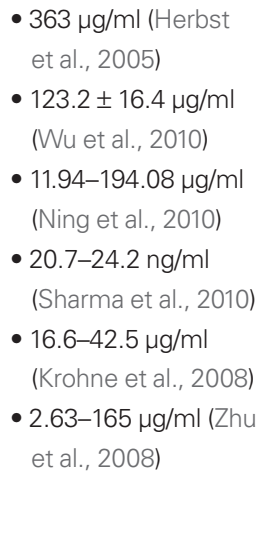 & $\begin{array}{l}\text { - 2-4 mg/kg, Mouse } \\
\text { carcinoma model } \\
\text { (Sims et al., 2008) } \\
\text { - } C_{\text {max }} 104.46 \pm 1.44 \text { ng/ } \\
\text { ml, injection in rabbit } \\
\text { (Kim et al., 2010) } \\
\text { - } C_{\max } 1430 \pm 186 \text { ng/ } \\
\text { ml, vitreous injection } \\
\text { macaque eyes } \\
\text { (Miyake et al., 2010) } \\
\text { - C } 676 \pm 100 \text { mg/ } \\
\text { ml, cynomolgus } \\
\text { monkeys (Xu et al., } \\
\text { 2008) }\end{array}$ \\
\hline
\end{tabular}

\section{ACKNOWLEDGMENTS}

We thank Ms. Paula Helpiölä, Ms. Mirja Hyppönen, and Ms. Hilkka Mäkinen for excellent technical assistance. The English language was checked by Virve Kajaste, MA, USA. Erlotinib was a kind gift

\section{REFERENCES}

Ai, S., Cheng, X. W., Inoue, A., Nakamura, K., Okumura, K., Iguchi, A., Murohara, T., and Kuzuya, M. (2007). Angiogenic activity of bFGF and VEGF suppressed by proteolytic cleavage by neutrophil elastase. Biochem. Biophys. Res. Commun. 364, 395-401.

Akhtar, N., Dickerson, E. B., and Auerbach, R. (2002). The sponge/Matrigel angiogenesis assay. Angiogenesis 5, 75-80.

Auerbach, R., Lewis, R., Shinners, B., Kubai, L., and Akhtar, N. (2003). Angiogenesis assays: a critical overview. Clin. Chem. 49, 32-40.

Bae, S. K., Seo, K. A., Jung, E. J., Kim, H. S., Yeo, C. W., Shon, J. H., Park, K. M., Liu, K. H., and Shin, J. G. (2008). Determination of acetylsalicylic acid and its major metabolite, salicylic acid, in human plasma using liquid chromatography-tandem mass spectrometry: application to pharmacokinetic study of Astrix in Korean healthy volunteers. Biomed. Chromatogr. 22, 590-595.

Beilmann, M., Birk, G., and Lenter, M. C. (2004). Human primary co-culture angiogenesis assay reveals additive stimulation and different angiogenic properties of VEGF and HGF. Cytokine 26, 178-185.

Berthod, F., Germain, L., Tremblay, N., and Auger, F. A. (2006). Extracellular matrix deposition by fibroblasts is necessary to promote capillary-like tube formation in vitro. J. Cell. Physiol. 207, 491-498.

Birle, D. C., and Hedley, D. W. (2006). Signaling interactions of rapamycin combined with erlotinib in cervical carcinoma xenografts. Mol. Cancer Ther. 5, 2494-2502.

Bishop, E. T., Bell, G. T., Bloor, S., Broom, I. J., Hendry, N. F., and Wheatley, D. N. (1999). An in vitro model of angiogenesis: basic features. Angiogenesis 3, 335-344.

Borthwick, G. M., Johnson, A. S., Partington, M., Burn, J., Wilson, R., and Arthur, H.M. (2006). Therapeutic levels of aspirin and salicylate directly inhibit a model of angiogenesis through a Cox-independent mechanism. FASEB J. 20, 2009-2016.

Brahn, E., Banquerigo, M. L., Lee, J. K., Park, E. J., Fogler, W. E., and Plum, S. M. (2008). An angiogenesis inhibitor, 2-methoxyestradiol, involutes rat collagen-induced arthritis and suppresses

from Roche Diagnostics GmbH. Funding for the project was provided by Pirkanmaa Centers for Economic Development, Transport and the Environment, City of Tampere, Ministry of Education and Culture and Ministry of Agriculture and Forestry.

gene expression of synovial vascular endothelial growth factor and basic fibroblast growth factor. J. Rheumatol. $35,2119-2128$.

Cao, Y. (2009). Monotherapy versus combination therapy of angiogenic and arteriogenic factors for the treatment of ischemic disorders. Curr. Mol. Med. 9, 967-972.

Cerniglia, G. J., Pore, N., Tsai, J. H., Schultz, S., Mick, R., Choe, R., Xing, X., Durduran, T., Yodh, A. G., Evans, S. M., Koch, C. J., Hahn, S. M., Quon, H., Sehgal, C. M., Lee, W. M., and Maity, A. (2009). Epidermal growth factor receptor inhibition modulates the microenvironment by vascular normalization to improve chemotherapy and radiotherapy efficacy. PLoS ONE 4, e6539. doi: 10.1371/ journal.pone.0006539

Clarke, J. L., Pao, W., Wu, N., Miller, V. A., and Lassman, A. B. (2010). High dose weekly erlotinib achieves therapeutic concentrations in CSF and is effective in leptomeningeal metastases from epidermal growth factor receptor mutant lung cancer. J. Neurooncol. 99, 283-286.

Cross, M. J., and Claesson-Welsh, L. (2001). FGF and VEGF function in angiogenesis: signalling pathways, biological responses and therapeutic inhibition. Trends Pharmacol. Sci. 22, 201-207.

Dahl, O., Fluge, O., Carlsen, E., Wiig, J. N. Myrvold, H. E., Vonen, B., Podhorny, N., Bjerkeset, O., Eide, T. J., Halvorsen, T. B., and Tveit, K. M. (2009). Final results of a randomised phase III study on adjuvant chemotherapy with $5 \mathrm{FU}$ and levamisol in colon and rectum cancer stage II and III by the Norwegian Gastrointestinal Cancer Group. Acta Oncol. 48, 368-376.

Dahut, W. L., Lakhani, N. J., Gulley, J. L., Arlen, P. M., Kohn, E. C., Kotz, H., McNally, D., Parr, A., Nguyen, D., Yang, S. X., Steinberg, S. M., Venitz, J., Sparreboom, A., and Figg, W. D. (2006). Phase I clinical trial of oral 2-methoxyestradiol, an antiangiogenic and apoptotic agent, in patients with solid tumors. Cancer Biol. Ther. 5, 22-27.

Dobos, J., Timar, J., Bocsi, J., Burian, Z., Nagy, K., Barna, G., Petak, I., and Ladanyi, A. (2004). In vitro and in vivo antitumor effect of 2-methoxyestradiol on human melanoma. Int. J. Cancer 112, 771-776. 
Dondorp, A. M., Silamut, K., Charunwatthana, P., Chuasuwanchai, S., Ruangveerayut, R., Krintratun, S., White, N. J., Ho, M., and Day, N. P. (2007). Levamisole inhibits sequestration of infected red blood cells in patients with falciparum malaria. $J$. Infect. Dis. 196, 460-466.

Donovan, D., Brown, N. J., Bishop, E. T., and Lewis, C. E. (2001). Comparison of three in vitro human "angiogenesis" assays with capillaries formed in vivo. Angiogenesis 4, 113-121.

Dubey, R. K., and Jackson, E. K. (2009). Potential vascular actions of 2-methoxyestradiol. Trends Endocrinol. Metab. $20,374-379$.

Folkman, J. (2006). Angiogenesis. Annu. Rev. Med. 57, 1-18.

Friis, T., Engel,A.M., Klein, B. M., Rygaard, J., and Houen, G. (2005). Levamisole inhibits angiogenesis in vitro and tumor growth in vivo. Angiogenesis $8,25-34$.

Friis, T., Hansen, A. B., Houen, G., and Engel, A. M. (2006). Influence of angiogenesis inhibitors on endothelial cell morphology in vitro. APMIS 114, 211.

Friis, T., Kjaer Sorensen, B., Engel, A. M., Rygaard, J., and Houen, G. (2003). A quantitative ELISA-based co-culture angiogenesis and cell proliferation assay. APMIS 111, 658-668.

Greenberg, S., and Rugo, H. S. (2010). Triple-negative breast cancer: role of antiangiogenic agents. Cancer J. 16, 33-38.

Harrison, M. R., Hahn, N. M., Pili, R., Oh, W. K., Hammers, H., Sweeney, C., Kim, K., Perlman, S., Arnott, J., Sidor, C., Wilding, G., and Liu, G. (2010). A phase II study of 2-methoxyestradiol (2ME2) NanoCrystal(R) dispersion (NCD) in patients with taxane-refractory, metastatic castrate-resistant prostate cancer (CRPC). Invest. New Drugs doi: 10.1007/s10637-0109455-x. [Epub ahead of print].

Herbst, R. S., Johnson, D. H., Mininberg, E., Carbone, D. P., Henderson, T., Kim, E. S., Blumenschein, G. Jr., Lee, J. J., Liu, D. D., Truong, M. T., Hong, W. K., Tran, H., Tsao, A., Xie, D., Ramies, D. A., Mass, R., Seshagiri, S., Eberhard, D. A., Kelley, S. K., and Sandler, A. (2005). Phase I/II trial evaluating the antivascular endothelial growth factor monoclonal antibody bevacizumab in combination with the HER-1/epidermal growth factor receptor tyrosine kinase inhibitor erlotinib for patients with recurrent non-small-cell lung cancer. J. Clin. Oncol. 23, 2544-2555.

Ishikane, S., Ohnishi, S., Yamahara, K., Sada, M., Harada, K., Mishima, K., Iwasaki, K., Fujiwara, M., Kitamura, S., Nagaya, N., and Ikeda, T. (2008). Allogeneic injection of fetal mem- brane-derived mesenchymal stem cells induces therapeutic angiogenesis in a rat model of hind limb ischemia. Stem Cells 26, 2625-2633.

Jaffe, E. A., Nachman, R. L., Becker, C. G., and Minick, C. R. (1973). Culture of human endothelial cells derived from umbilical veins. Identification by morphologic and immunologic criteria. J. Clin. Invest. 52, 2745-2756.

James, J., Murry, D. J., Treston, A. M., Storniolo, A. M., Sledge, G. W., Sidor, C., and Miller, K. D. (2007). Phase I safety, pharmacokinetic and pharmacodynamic studies of 2-methoxyestradiol alone or in combination with docetaxel in patients with locally recurrent or metastatic breast cancer. Invest. New Drugs 25, 41-48.

Jimeno, A., Kulesza, P., Wheelhouse, J., Chan, A., Zhang, X., Kincaid, E., Chen, R., Clark, D. P., Forastiere, A., and Hidalgo, M. (2007). Dual EGFR and mTOR targeting in squamous cell carcinoma models, and development of early markers of efficacy. $B r$. J. Cancer 96, 952-959.

Juárez Olguín, H., Flores Pérez, J., Lares Asseff, I., Loredo Abdalá, A., and Carbajal Rodriguez, L. (2004). Comparative pharmacokinetics of acetyl salicylic acid and its metabolites in children suffering from autoimmune diseases. Biopharm. Drug Dispos. 25, 1-7.

Kakimoto, T., Hattori, Y., Okamoto, S., Sato, N., Kamata, T., Yamaguchi, M., Morita, K., Yamada, T., Takayama, N., Uchida, H., Shimada, N., Tanigawara, Y., and Ikeda, Y. (2002). Thalidomide for the treatment of refractory multiple myeloma: association of plasma concentrations of thalidomide and angiogenic growth factors with clinical outcome. Jpn. J. Cancer Res. 93, 1029-1036.

Kamikawa, R., Ikawa, K., Morikawa, N., Asaoku, H., Iwato, K., and Sasaki, A. (2006). The pharmacokinetics of lowdose thalidomide in Japanese patients with refractory multiple myeloma. Biol. Pharm. Bull. 29, 2331-2334.

Kang, S. H., Cho, H. T., Devi, S., Zhang, Z., Escuin, D., Liang, Z., Mao, H., Brat, D. J., Olson, J. J., Simons, J. W., Lavallee, T. M., Giannakakou, P., Van Meir, E. G., and Shim, H. (2006). Antitumor effect of 2-methoxyestradiol in a rat orthotopic brain tumor model. Cancer Res. 66, 11991-11997.

Kim, M. J., Han, E. S., Kim, J., and Kim, T.W. (2010). Aqueous humor concentration of bevacizumab after subconjunctival injection in rabbit. J. Ocul. Pharmacol. Ther. 26, 49-53.

Kouassi, E., Caille, G., Lery, L., Lariviere, L., and Vezina, M. (1986). Novel assay and pharmacokinetics of levamisole and p-hydroxylevamisole in human plasma and urine. Biopharm. Drug Dispos. 7, 71-89.

Kraut, E. H., Rhoades, C., Zhang, Y., Cheng, H., Aimiumu, J., Chen, P., Lang, J., Young, D. C., Agrawal, A., Dancey, J., Chan, K. K., and Grever, M. R. (2010). Phase I and pharmacokinetic study of erlotinib (OSI-774) in combination with docetaxel in squamous cell carcinoma of the head and neck (SSCHN). Cancer Chemother. Pharmacol. doi: 10.1007/s00280-0101332-y. [Epub ahead of print].

Krohne, T. U., Eter, N., Holz, F. G., and Meyer, C.H. (2008). Intraocular pharmacokinetics of bevacizumab after a single intravitreal injection in humans. Am. J. Ophthalmol. 146, 508-512.

Maalouf, R., Mosley, M., James Kallail, K., Kramer, K. M., and Kumar, G. (2009). A comparison of salicylic acid levels in normal subjects after rectal versus oral dosing. Acad. Emerg. Med. 16, 157-161.

Matei, D., Schilder, J., Sutton, G., Perkins, S., Breen, T., Quon, C., and Sidor, C. (2009). Activity of 2 methoxyestradiol (Panzem NCD) in advanced, platinum-resistant ovarian cancer and primary peritoneal carcinomatosis: a Hoosier Oncology Group trial. Gynecol. Oncol. 115, 90-96.

Middleton, J., Americh, L., Gayon, R., Julien, D., Aguilar, L., Amalric, F., and Girard,J.P. (2004).Endothelial cell phenotypes in the rheumatoid synovium: activated, angiogenic, apoptotic and leaky. Arthritis Res. Ther. 6, 60-72.

Miyake, T., Sawada, O., Kakinoki, M., Sawada, T., Kawamura, H. Ogasawara, K., and Ohji, M. (2010). Pharmacokinetics of bevacizumab and its effect on vascular endothelial growth factor after intravitreal injection of bevacizumab in macaque eyes. Invest. Ophthalmol. Vis. Sci. 51 , 1606-1608.

Murakami, H., Shimizu, K., Sawamura, M., Suzuki, K., Sugiura, I., Kosugi, H., Shimazaki, C., Taniwaki, M., Abe, M. and Takagi, T. (2009). Phase II and pharmacokinetic study of thalidomide in Japanese patients with relapsed/ refractory multiple myeloma. Int. J. Hematol. 89, 636-641.

Nillesen, S. T., Geutjes, P. J., Wismans, R., Schalkwijk, J., Daamen, W. F., and van Kuppevelt, T.H. (2007). Increased angiogenesis and blood vessel maturation in acellular collagen-heparin scaffolds containing both FGF2 and VEGF Biomaterials 28, 1123-1131.

Ning, Y. M., Gulley, J. L., Arlen, P. M., Woo, S., Steinberg, S. M., Wright, J. J., Parnes, H. L., Trepel, J. B., Lee, M. J., Kim, Y. S. Sun, H., Madan, R.A., Latham, L., Jones, E., Chen, C. C., Figg, W. D., and Dahut, W. L. (2010). Phase II trial of bevacizumab, thalidomide, docetaxel, and prednisone in patients with metastatic castration-resistant prostate cancer. J. Clin. Oncol. 28, 2070-2076.

Norrby, K. (2006). In vivo models of angiogenesis. J. Cell Mol. Med. 10, 588-612.

Plum, S. M., Park, E. J., Strawn, S. J., Moore, E. G., Sidor, C. F., and Fogler, W. E. (2009). Disease modifying and antiangiogenic activity of 2-methoxyestradiol in a murine model of rheumatoid arthritis. BMC Musculoskelet. Disord. 10, 46. doi: 10.1186/14712474-10-46

Quasar Collaborative, G., Gray, R., Barnwell, J., McConkey, C., Hills, R. K., Williams,N. S., and Kerr, D. J. (2007) Adjuvant chemotherapy versus observation in patients with colorectal cancer: a randomised study. Lancet 370, 2020-2029.

Rajkumar, S. V., Richardson, P. G., Lacy, M. Q., Dispenzieri, A., Greipp, P. R., Witzig, T. E., Schlossman, R., Sidor, C. F., Anderson, K. C., and Gertz, M. A. (2007). Novel therapy with 2-methoxyestradiol for the treatment of relapsed and plateau phase multiple myeloma. Clin. Cancer Res. 13, 6162-6167.

Ranson, M., Shaw, H., Wolf, J., Hamilton, M., McCarthy, S., Dean, E., Reid, A., and Judson, I. (2010a). A phase I doseescalation and bioavailability study of oral and intravenous formulations of erlotinib (Tarceva, OSI-774) in patients with advanced solid tumors of epithelial origin. Cancer Chemother. Pharmacol. 66, 53-58.

Ranson, M., Reck, M., Anthoney, A., Hanauske, A. R., Dean, E., Melezinek, I., Klingelschmitt, G., Kletzl, H., Blatter, J., and Twelves, C. (2010b). Erlotinib in combination with pemetrexed for patients with advanced non-smallcell lung cancer (NSCLC): a phase I dose-finding study. Ann. Oncol. 21, 2233-2239.

Reid, J. M., Kovach, J. S., O'Connell, M. J., Bagniewski, P. G., and Moertel, C. G. (1998). Clinical and pharmacokinetic studies of high-dose levamisole in combination with 5-fluorouracil in patients with advanced cancer. Cancer Chemother. Pharmacol. 41, 477-484.

Rogers, P.A., Donoghue, J. F., Walter, L. M., and Girling, J. E. (2009). Endometrial angiogenesis, vascular maturation, and lymphangiogenesis. Reprod. Sci. $16,147-151$.

Ryu, J. K., and McLarnon, J. G. (2008). Thalidomide inhibition of perturbed vasculature and glial-derived tumor necrosis factor-alpha in an animal model of inflamed Alzheimer's disease brain. Neurobiol. Dis. 29, 254-266.

Sharma, S., Abhyankar, V., Burgess, R. E., Infante, J., Trowbridge, R. C., Tarazi, J., Kim, S., Tortorici, M., Chen, Y., and 
Robles, R. L. (2010). A phase I study of axitinib (AG-013736) in combination with bevacizumab plus chemotherapy or chemotherapy alone in patients with metastatic colorectal cancer and other solid tumors. Ann. Oncol. 21, 297-304.

Sharma, S., Ghoddoussi, M., Gao, P., Kelloff, G. J., Steele, V. E., and Kopelovich, L. (2001). A quantitative angiogenesis model for efficacy testing of chemopreventive agents. Anticancer Res. 21, 3829-3837.

Sims, T. L., Williams, R. F., Ng, C. Y., Rosati, S. F., Spence, Y., and Davidoff, A.M. (2008). Bevacizumab suppresses neuroblastoma progression in the setting of minimal disease. Surgery 144 269-275.

Sweeney, C., Liu, G., Yiannoutsos, C., Kolesar, J., Horvath, D., Staab, M. J., Fife, K., Armstrong, V., Treston, A., Sidor, C., and Wilding, G. (2005). A phase II multicenter, randomized, double-blind, safety trial assessing the pharmacokinetics, pharmacodynamics, and efficacy of oral 2-methoxyestradiol capsules in hormone-refractory prostate cancer. Clin. Cancer Res. 11, 6625-6633.

Sylvest, L., Bendiksen, C. D., and Houen, G. (2010). Phosphatase inhibitors with anti-angiogenic effect in vitro. APMIS 118, 49-59.
Taylor, S. M., Mallon, T., and Carrol, B. (1988). Efficacy of a levamisole bolus in ostertagia and cooperia infections. Ann. Rech. Vet. 19, 107-110.

Tevaarwerk, A. J., Holen, K. D., Alberti, D. B., Sidor, C., Arnott, J., Quon, C., Wilding, G., and Liu, G. (2009). Phase I trial of 2-methoxyestradiol nanoCrystal dispersion in advanced solid malignancies. Clin. Cancer Res. 15, 1460-1465.

Ucuzian, A. A., and Greisler, H. P. (2007). In vitro models of angiogenesis. World J. Surg. 31, 654-663.

van Weel, V., van Tongeren, R. B., van Hinsbergh, V. W., van Bockel, J. H., and Quax, P. H. (2008). Vascular growth in ischemic limbs: a review of mechanisms and possible therapeutic stimulation. Ann. Vasc. Surg. 22, 582-597.

Verma, S., Quirt, I., McCready, D., Bak, K., Charette, M., and Iscoe, N. (2006). Systematic review of systemic adjuvant therapy for patients at high risk for recurrent melanoma. Cancer 106, 1431-1442.

Vieira, J. L., and Valente Mdo, S. (2009). Thalidomide levels in patients with erythema nodosum leprosum. Ther. Drug Monit. 31, 602-603.

Wu, J. Y., Wu, X. N., Ding, L., Zhao, Y. B. Ai, B., Li, Y., Hu, X., and Cheng, G.
(2010). Phase I safety and pharmacokinetic study of bevacizumab in Chinese patients with advanced cancer. Chin. Med. J. 123, 901-906.

Xu,L.,Zuch, C.L., Lin, Y.S., Modi, N.B., and Lum, B. L. (2008). Pharmacokinetics and safety of bevacizumab administered in combination with cisplatin and paclitaxel in cynomolgus monkeys. Cancer Chemother. Pharmacol. 61, 607-614.

Yan, K. H., Yao, C. J., Chang, H. Y., Lai, G. M., Cheng, A. L., and Chuang, S. E. (2010). The synergistic anticancer effect of troglitazone combined with aspirin causes cell cycle arrest and apoptosis in human lung cancer cells. Mol. Carcinog. 49, 235-246.

Zhang, H., Shan, C., Hua, Z., Zhao, P. and Zhang, H. (2009). Treatment of chronic idiopathic urticaria with levamisole: a multicentre, randomized, double-blind, controlled trial. J. Int. Med. Res. 37, 1167-1172.

Zhu, Q., Ziemssen, F., Henke-Fahle, S. Tatar, O., Szurman, P., Aisenbrey, S. Schneiderhan-Marra, N., Xu, X., and Grisanti, S. (2008). Vitreous levels of bevacizumab and vascular endothelial growth factor-A in patients with choroidal neovascularization. Ophthalmology 115, 1750-1755.
Ziche, M., and Morbidelli, L. (2009). The corneal pocket assay. Methods Mol. Biol. 467, 319-329.

Conflict of Interest Statement: The authors declare that the research was conducted in the absence of any commercial or financial relationships that could be constructed as a potential conflict of interest.

Received: 09 June 2010; paper pending published: 20 September 2010; accepted: 31 December 2010; published online: 20 January 2011.

Citation: Sarkanen J-R, Mannerström M, Vuorenpää H, Uotila J, Ylikomi T and Heinonen T (2011) Intra-laboratory pre-validation of a human cell based in vitro angiogenesis assay for testing angiogenesis modulators. Front. Pharmacol. 1:147. doi: 10.3389/fphar.2010.00147

This article was submitted to Frontiers in Predictive Toxicity, a specialty of Frontiers in Pharmacology.

Copyright (c) 2011 Sarkanen, Mannerström, Vuorenpää, Uotila, Ylikomi and Heinonen. This is an open-access article subject to an exclusive license agreement between the authors and Frontiers Media $S A$, which permits unrestricted use, distribution, and reproduction in any medium, provided the original authors and source are credited. 